\title{
Effect of EPA on Hsp90 and GRa protein expression in multiple myeloma drug- resistant cells
}

\author{
Shenghao Wu*, Yuemiao Chen, Xueshuang Wang, Shanshan Weng, Wenjin Zhou and Zhen Liu
}

\begin{abstract}
Background: Approximately 20\% of MM patients harbor glucocorticoid (GC) resistance and are not responsive to therapeutic effect. Chaperoneheat-shock proteins Hsp90 is needed for ligand docking, The imbalance of Hsp90/GRa (glucocorticoid receptor a) may be an important cause of GC resistance. Recent studies have indicated that EPA could repress cancer cell growth by regulating critical influential factors in progression of cancer, consisting of resistance to drugs, chemosensitivity. The aim of the present study was to test the cytotoxic effects of EPA alone or EPA + Dexamethasone in dexamethasone-resistant MM cell (MM.1R) and investigate whether DHA can induce apoptosis and reverse acquired glucocorticoid resistance in dexamethasone-resistant MM cell (MM.1R).

Methods: Cell Counting Kit-8 (CCK-8) was used to detect the proliferation of MM.1R cells after treating with EPA alone and EPA combined with DEX. Mitochondrial membrane potential was measured by flow cytometry and GRa and Hsp90 protein expression were assessed by western blot analysis.

Results: EPA alone was able to inhibit cell proliferation as evidenced by CCK-8 assay and the tumor growth was remarkably suppressed by EPA + Dexamethasone, Cell apoptosis after EPA treatment was obviously observed by Flow cytometry analysis of the mitochondrial membrane potential. Analysis of Hsp90 and GRa proteins in MM.1R cells incubated with EPA revealed down-regulation of Hsp90 and up-regulation of GRa. Accordingly, the Hsp90/GRa ratio was significantly decreased with the increase of EPA concentration.
\end{abstract}

Conclusions: EPA might be used as a new effective treatment for reversal of glucocorticoid-resistance in multiple myeloma.

Keywords: Myeloma, EPA, Heat shock protein-90, GRa, Apoptosis

\section{Introduction}

Multiple myeloma (MM) is a hematological tumor of terminally differentiated bone marrow (BM)-resident B lymphocytes referred to as plasma cells (PCs) [1]. Despite improvementsin the understanding of its biology, MM is still an incurable disease due to treatment-related mutations and drug resistance [2]. Therefore, new treatment

\footnotetext{
* Correspondence: wushenghao30@gmail.com

Department of Hematology, The Second Affiliated Hospital of Shanghai University (The Dingli Clinical Institute of Wenzhou Medical University, Wenzhou Central Hospital), No.252 East Baili Road, Lucheng District, Wenzhou 325000, Zhejiang Province, China
}

strategiesthat target either metastatic plasma cells or the microenvironment of bone marrow can be considered for MM. Glucocorticoids (GCs) are an important agentemployed in all therapeutic formulations for treating leukemia, as well as multiple myeloma. The killing mechanisms of glucocorticoids include triggering the apoptosis of myeloma cells and decreasing poly (ADP ribose) polymerase cleavage, mitochondrial transmembrane potential and caspase 3 expression [3]. Nevertheless, approximately $20 \%$ of patients harbor glucocorticoid resistance and are not responsive to treatment. Moreover, those who are

(c) The Author(s). 2021 Open Access This article is licensed under a Creative Commons Attribution 4.0 International License, which permits use, sharing, adaptation, distribution and reproduction in any medium or format, as long as you give appropriate credit to the original author(s) and the source, provide a link to the Creative Commons licence, and indicate if changes were made. The images or other third party material in this article are included in the article's Creative Commons licence, unless indicated otherwise in a credit line to the material. If material is not included in the article's Creative Commons licence and your intended use is not permitted by statutory regulation or exceeds the permitted use, you will need to obtain permission directly from the copyright holder. To view a copy of this licence, visit http://creativecommons.org/licenses/by/4.0/ The Creative Commons Public Domain Dedication waiver (http://creativecommons.org/publicdomain/zero/1.0/) applies to the data made available in this article, unless otherwise stated in a credit line to the data. 
responsive may develop glucocorticoid resistance along the treatment time course, resulting in relapse and a very dismal prognosis. However, some new findings provide new tools for overcoming glucocorticoid resistance [4]. Enhancing glucocorticoid sensitivity is a growing challenge in the treatment of MM. Diverse mechanisms of resistance to glucocorticoids have been reported in MM. Functional abnormalities of the glucocorticoid receptor underlie the occurrence of glucocorticoid resistance. A truncated glucocorticoid receptor (GR) without the Cterminal hormone docking domain has been reported in dexamethasone (DEX)-resistant MM cells [5]. There are two primary GR isoforms ( $\alpha$ and $\beta$ ), with the GR $\alpha$ isoform being the only GC functional receptor [6]. Studies have suggested that GR $\beta$ has a prominent negative influence on GR $\alpha$ via GR $\alpha / G R \beta$ heterodimer formation, which prevents $\mathrm{GR} \alpha$ action [7, 8]. Unstimulated GRs remain in the cytoplasm as heterocomplexes with chaperone heat-shock proteins, Hsp90, and Hsp70. Hsp90 is needed for ligand docking, and Hsp70 is believed to facilitate ligand delivery to Hsp90 [9]. However, the overexpression of Hsp90 has been documented to negatively modulate GR promoter activity, repress GR transcription, and decrease GR inclusion in cytoplasm complexes $[10,11]$.

Eicosapentaenoic acid (EPA) and docosahexaenoic acid (DHA) are long-chain PUFAs. These PUFAs play pivotal functions in the cell as structural compartments of cellular membranes and as mediators of intracellular metabolic cascades. PUFAs have advantageous activities in diverse chronic conditions, such as neurodegenerative disorders, inflammatory conditions, cardiovascular diseases, and cancers [12-15]. Studies have indicated that EPA, as well as DHA, repress cancer cell growth and survival by regulating critical influential factors in the progression of cancer, including drug resistance, chemosensitivity and angiogenesis [16-19]. The mechanism of cancer cell suppression by PUFAs involvesthe induction of apoptosis [20, 21]. Lipid peroxidation causes irreversible cell damage [22-24] and modulates gene expression, including that oftranscription factors [25-28].

A previous study reported Hsp90 overexpression in multiple malignant cell types, including MM. To our knowledge, no previous studies have examined whether DHA can decrease Hsp90 inclusion in the GR complex, induce apoptosis, and reverse acquired glucocorticoid resistance in dexamethasone-resistant MM cells (MM.1R). Considering the anticancer capacity of DHA along with its limited side effects on healthy cells, we explored the effect of DHA on Hsp90 and GR $\alpha$ expression in multiple myeloma cells.

\section{Materials and methods}

\section{Reagents and antibodies}

DEX-resistant human multiple myeloma cells (MM.1R) were purchased from the Cell Bank of the Chinese
Academy of Sciences (Shanghai, China) and were preserved in our laboratory. Then, they were removed from liquid nitrogen and characterized. Conventional resuscitation and subculture of MM.1R cells were performed. RPMI 1640 medium and fetal bovine serum (FBS) were purchased from Gibco (NY, USA). EPA and DEX were purchased from Sigma, cell cycle detection kits and flow cytometry apoptosis detection kits were purchased from KeyGEN Biotech (Nanjing, China). anti-GR $\alpha$ antibodies (11000), anti-Hsp90 antibody and GAPDH antibody were purchased from Abcam, the protein lysate, BCA protein concentration determination kit, fluorescent secondary antibody, ECL chemiluminescence kit, and CCK8 kit were purchased from BiYunTian Biotech Company (Shanghai, China).

\section{Cell culture experiments}

MM.1R cells were inoculated in DMEM enriched with fetal bovine serum (10\%), streptomycin $(100 \mathrm{U} / \mathrm{ml})$, and penicillin $(100 \mathrm{U} / \mathrm{ml})$ and then incubatedin an incubator programmed at $37{ }^{\circ} \mathrm{C}$ and $5 \% \mathrm{CO}_{2}$. The growth media was refreshed every 2-3 days, and passaging of the cells was performed accordingly, logarithmic-phase cells were selected for downstream experiments.

\section{Group allocation}

DEX was suspended in $0.05 \%$ DMSO, dissolved to form a stock solution at a concentration of $10 \mathrm{mmol} / \mathrm{l}$, and then diluted 1000 times with RPMI 1640 medium. The final DEX concentration was adjusted to $10 \mu \mathrm{mol} / \mathrm{L}$. EPA reserve solution $(100 \mathrm{mmol} / \mathrm{L})$ was prepared with anhydrous ethanol. The working solution $(10,20,50$, $100 \mu \mathrm{mol} / \mathrm{L}$ ) was then preparedby diluting the stock solution with RPMI1640. In the combined dosing group, different concentrations of EPA were incubated for $12 \mathrm{~h}$. An additional $10 \mu \mathrm{mol} / \mathrm{L}$ DEX was introduced, and incubation was continued for $24 \mathrm{~h}$, and then further experiments were performed. Equal volumes of medium were introduced to the control group. The growth of the control cells was assessed in medium with a similar concentration of DMSO or anhydrous ethanol as the DHA-containing medium. EPA treatments at concentrations of $10-50 \mu \mathrm{mol} / \mathrm{L}$ remarkably suppressed cell proliferation.

\section{Cell proliferation evaluation by the CCK-8 assay}

Cells in the logarithmic growth phase were collected. Digestion of the cells was performed using $0.25 \%$ trypsin, followed by cell suspension preparation. We adjusted the cell density to $1 \times 10^{5}$ cells $/ \mathrm{ml}$. Thereafter, the cells were plated in 96 -well plates $(200 \mu \mathrm{l} /$ well $)$. The experiments were performed in 5 replicate wells. The cells were grown for $24 \mathrm{~h}$ in an incubator programmed at $37^{\circ} \mathrm{C}, 5 \% \mathrm{CO} 2$, and saturated humidity. After the cells 
were allowed to grow and adhere for $24 \mathrm{~h}$, the drug solution was added to the cells at various concentrations. CCK- 8 reagent $(10 \mu \mathrm{l})$ was added to each well, the samples were thoroughly mixed, and the plates were placed in an incubator for $2 \mathrm{~h}$. Absorbance values (OD values) were determined at $450 \mathrm{~nm}$ using an enzyme standard instrument and used in the following formula:cell growth inhibition rate $=($ test $\mathrm{OD}$ value - blank OD value $) /($ control OD value - blank OD value $) \times 100 \%$. Bar graphs of the final value were generated, and the results were analyzed. The experiment was replicated three times, and the results were averaged.

\section{Flow cytometry analysis of the mitochondrial membrane potential}

A mitochondrial membrane potential assay kit with JC-1 was employed to evaluate the mitochondrial membrane capacity. MM.1R cells in the logarithmic growth phase were plated $\left(1 \times 10^{5}\right.$ cells/well $)$ in 6 -well plates $(2 \mathrm{ml}$ per well), and then different concentrations of drugs were added. Cells were collected through centrifugation $48 \mathrm{~h}$ after the treatment. Samples were then rinsed with icecold PBS. Staining of the cells with $500 \mu \mathrm{l} \mathrm{JC-1}$ working solution was carried out at $37^{\circ} \mathrm{C}$ for $15 \mathrm{~min}$, and the cells were collected after sedimentation. After that, $500 \mu \mathrm{l}$ preheated JC-1 assay buffer was used to resuspend the cells, which were analyzed on a flow cytometer. The assay was replicated three times, and the average result was used.

\section{Western blot analysis of GRa and Hsp90 protein expression}

The cells were processed as described above. The MM.1R cells were treated as stated above. After treatment for $24 \mathrm{~h}$, the cells were collected, and protein purification was conducted using RIPA lysis buffer. The culture supernatants was collected and centrifuged to remove any cell debris. Quantitation of the total protein was conducted using the $\mathrm{BCA}^{\mathrm{m}}$ protein assay (Pierce). Fractionation of the total protein was performed using SDS-PAGE. After that, the proteins were transferembedded onto PVDF membranes. Blocking of the nonspecific sites was performed via a1-h incubation of the protein-embedded membranes with Tris-buffered salineTween 20 (TBST) enriched with 3\% bovine serum albumin at room temperature. Thereafter, incubation with primary antibody was conducted overnight in an incubator set at $4{ }^{\circ} \mathrm{C}$. Subsequently, the samples were rinsed three times with TBST, and then conjugation with the secondary antibodies at a 1:5000 dilution for $2 \mathrm{~h}$ was performed via incubation at room temperature. After washing, color development of the protein bands was carried out using ECL for 3-5 min. The band intensity for each protein was scanned on a scanner and analyzed using Image Quant 5.1 image processing software. GAPDH was employed as a reference gene. Relative quantitative analysis was also performed using Image Quant 5.1 software. The ratio of the optical density of the target protein to that of GAPDH was computed as the relative expression level of the target protein in the samples. This experiment was performed three times, and the results are presented as averaged values.

\section{Statistical analyses}

SPSS 16.0 software was applied in statistical analyses. All data are indicated as the mean \pm standard deviation $(\mathrm{SD})$, and a two-sample independent $\mathrm{t}$ test was used. $P<0.05$ signified statistical significance.

\section{Result}

The influence of EPA on the proliferation of MM.1R cells EPA treatment at concentrations of $10-50 \mu \mathrm{M}$ remarkably suppressed cell proliferation $(P<0.05$ for all). In comparison to the single-drug treatments, the combination of EPA and DEX remarkably repressed cell growth. There was a statistically significant difference between the two groups at the same time point $(P<0.05)$. At a given time point $(24$ or $48 \mathrm{~h}$ ), different concentrations of EPA had significantly different effects on the proliferation inhibition rate of MM.1R cells (Table 1).

\section{The influence of EPA on the mitochondrial membrane potential of MM.1R cells}

One mechanism through which apoptosis occurs entails mitochondrial membrane integrity loss, as well as the loss of transmembrane potential (i.e., collapse of $\Delta \psi \mathrm{m}$ ). Changes in mitochondrial membrane potential, $\Delta \Psi \mathrm{m}$, are a pivotal step in cells undergoing apoptosis. We explored the impact of EPA on mitochondrial membrane potential via astaining approach with the fluorescent membrane-permeant JC-1 dye and subsequent flow cytometric analysis. JC-1 accumulation is shown by red fluorescence, the $\mathrm{JC}-1$ monomer is indicated by green fluorescence, and the merged image combines the red and green images. Confocal microscopy demonstrated that EPA reduced red $\mathrm{JC}-1$ fluorescence and increased green $\mathrm{JC}-1$ fluorescence, leading to a reduction in the red/green fluorescence ratio. The fluorescence intensity gradually decreased with the progressive increase of EPA concentration and mitochondrial membrane potential in MM.1R cells drop to the maximum extent in the combined treatment group of EPA + dexamethasone $(P<0.05)$ (Fig. 1$)$.

\section{Western blot verification of Hsp90 and GRa protein expression}

MM.1R cells were simultaneously treated with different concentrations of EPA for 24h. The Hsp90 content 
Table 1 The influence of eicosapentaenoic acid (EPA) combined with dexamethasone (DEX) on the growth of MM.1R cells (\%,- $x \pm s$ )

\begin{tabular}{|c|c|c|}
\hline \multirow[t]{2}{*}{ Group } & \multicolumn{2}{|c|}{ The rate of cell proliferation inhibition } \\
\hline & $24 \mathrm{~h}$ & $48 \mathrm{~h}$ \\
\hline Control & 0 & 0 \\
\hline $10 \mu \mathrm{mol} / \mathrm{L}$ DEX & 0 & $5.47 \pm 0.25^{\mathrm{ac}}$ \\
\hline $10 \mu \mathrm{mol} / \mathrm{L}$ EPA & $8.45 \pm 0.57^{\mathrm{a}}$ & $12.07 \pm 0.94^{\mathrm{ac}}$ \\
\hline $20 \mu \mathrm{mol} / \mathrm{L}$ EPA & $15.24 \pm 1.27^{\mathrm{a}}$ & $24.59 \pm 1.29^{\mathrm{ac}}$ \\
\hline $50 \mu \mathrm{mol} / \mathrm{L}$ EPA & $21.97 \pm 2.14^{\mathrm{a}}$ & $35.47 \pm 2.416^{\mathrm{ac}}$ \\
\hline $50 \mu \mathrm{mol} / \mathrm{L}$ EPA + $10 \mu \mathrm{mol} / \mathrm{L}$ DEX & $38.78 \pm 2.73^{\mathrm{ab}}$ & $68.24 \pm 2.02^{\mathrm{abc}}$ \\
\hline
\end{tabular}

Note: Compared with the blank control group, ${ }^{a} P<0.05$; compared with the $50 \mu \mathrm{mol} / \mathrm{L}$ EPA group, ${ }^{\mathrm{b}} P<0.05$; compared with the $24 \mathrm{~h}$ group, ${ }^{\mathrm{C}} P<0.05$. $n=3$

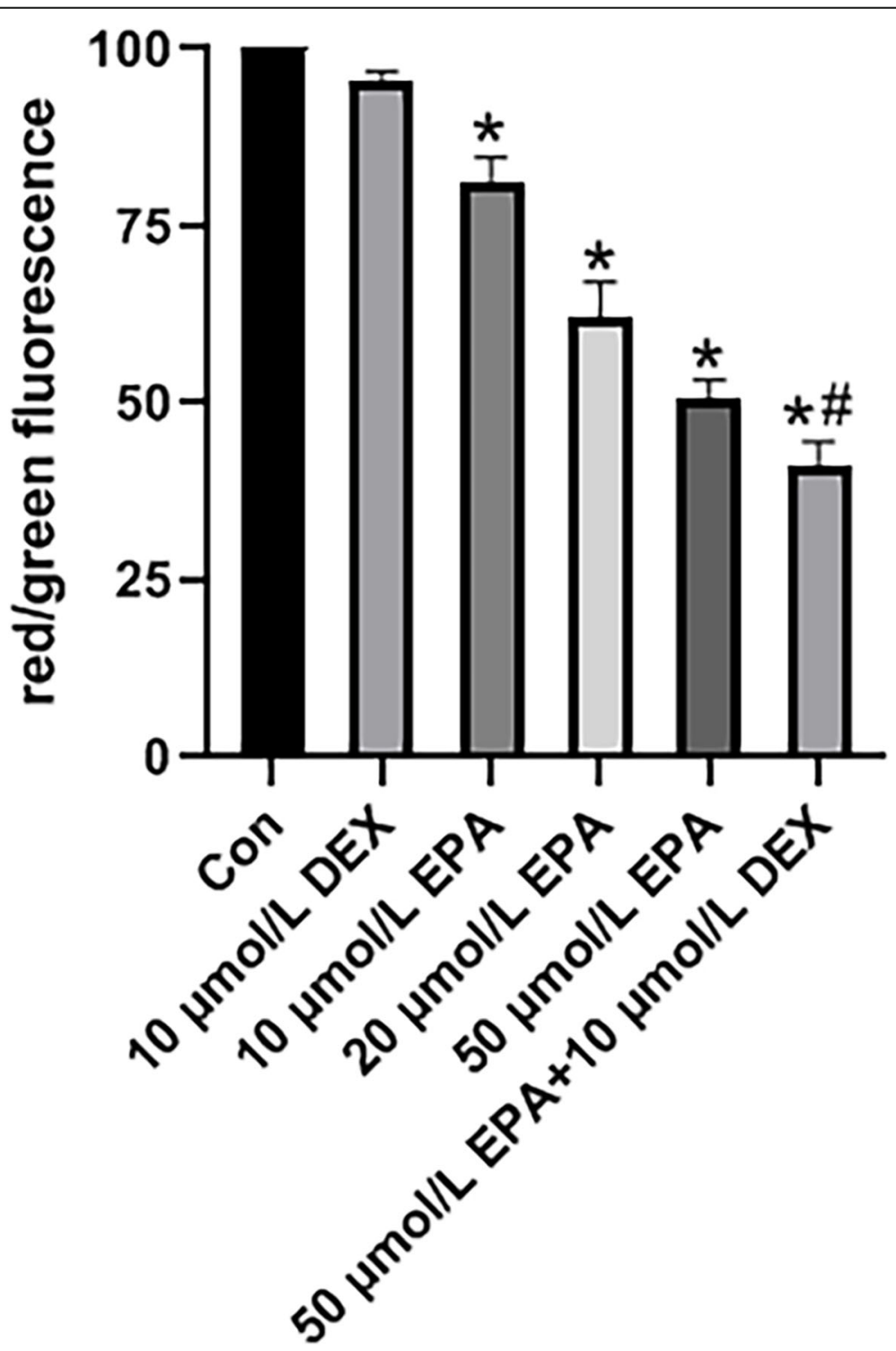

Fig. 1 Effect of EPA on MM.1R apoptosis through the mitochondrial pathway. Cells were exposed to $10 \mu \mathrm{mol} / \mathrm{L}$ DEX, $10 \mu \mathrm{mol} / \mathrm{L}$ EPA, $20 \mu \mathrm{mol} / \mathrm{L}$ $\mathrm{EPA}, 50 \mu \mathrm{mol} / \mathrm{L} \mathrm{EPA}$, and $50 \mu \mathrm{mol} / \mathrm{L}$ EPA $+10 \mu \mathrm{mol} / \mathrm{L}$ DEX for $48 \mathrm{~h}$. Mitochondrial membrane potential was measured via JC-1 staining. Illustrative images of JC-1-derived fluorescence in MM.1R cells. Quantitative evaluation of the ratio of red/green fluorescence. ${ }^{*} P<0.05$ vs. control; \#P $<0.05$ vs. $50 \mu \mathrm{mol} / \mathrm{L}$ EPA, $n=3$ 
Table 2 The influence of EPA on Hsp90 and GRa protein expression $\left(\%,{ }^{-} \mathrm{x} \pm \mathrm{s}\right)$

\begin{tabular}{llll}
\hline Group & Hsp90 & GRa & Hsp90/GRa \\
\hline Control & $2.91 \pm 0.03$ & $0.85 \pm 0.03$ & $3.39 \pm 0.11$ \\
$10 \mu \mathrm{mol} / \mathrm{L}$ DEX & $2.90 \pm 0.04$ & $0.87 \pm 0.02$ & $3.32 \pm 0.12$ \\
$10 \mu \mathrm{mol} / \mathrm{L} \mathrm{EPA}$ & $2.53 \pm 0.05^{\mathrm{a}}$ & $1.76 \pm 0.03^{\mathrm{a}}$ & $1.44 \pm 0.05^{\mathrm{a}}$ \\
$20 \mu \mathrm{mol} / \mathrm{L}$ EPA & $2.05 \pm 0.03^{\mathrm{a}}$ & $2.31 \pm 0.04^{\mathrm{a}}$ & $0.88 \pm 0.02^{\mathrm{a}}$ \\
$50 \mu \mathrm{mol} / \mathrm{L} \mathrm{EPA}$ & $1.83 \pm 0.05^{\mathrm{a}}$ & $2.76 \pm 0.04^{\mathrm{a}}$ & $0.66 \pm 0.02^{\mathrm{a}}$ \\
$50 \mu \mathrm{mol} / \mathrm{L}$ EPA $+10 \mu \mathrm{mol} / \mathrm{L}$ DEX & $1.58 \pm 0.03^{\mathrm{ab}}$ & $2.97 \pm 0.08^{\mathrm{ab}}$ & $0.53 \pm 0.01^{\mathrm{ab}}$ \\
\hline
\end{tabular}

Note: Compared with the blank control group, ${ }^{\mathrm{a}} P<0.05$; compared with the $50 \mu \mathrm{mol} / \mathrm{L}$ EPA group, ${ }^{\mathrm{b}} P<0.05 . \mathrm{n}=3$

decreased gradually with increasing EPA concentration, and the expression of Hsp90 decreased significantly in the combined EPA + dexamethasone group. GR $\alpha$ increased gradually with increasing EPA concentration, and when EPA was combined with dexamethasone. The effect appeared to be dose dependent. Accordingly, the ratio of Hsp90 to GR $\alpha$ expression decreased gradually with increasing EPA concentration $(P<0.05)$ (Table 2, Fig. 2).

\section{Discussion}

Herein, the efficacy of EPA in triggering cell apoptosis was explored in MM cells. We established that treatment of MM cells using different concentrations of EPA causes remarkable apoptotic death in timedependentand dose-dependent manners. EPA reduced the mitochondrial membrane potential in MM cells, implying that the apoptosis of MM cells was partly caspase-dependent. The proliferation assay showed that EPA exhibited a comparable inhibitory role with DEX in MM.1R cells. The differences in metabolism and structure between malignant cells and the corresponding healthy cells account for the reported effect of EPA on malignant plasma cells, making malignant cells more vulnerable to the cytotoxic influence of EPA. EPA destroys mitochondria to reduce mitochondrial membrane potential and ultimately induces apoptosis in MM.1R cells. Intriguingly, the effects of EPA on cell apoptosis in acute myeloid leukemia cells were linked to mitochondrial metabolism disruption, the stimulation of mitochondrial swelling, and the reduction of mitochondrial membrane potential and were correlated with elevated oxidative stress and the dysregulation of Nrf2 [29].

Chaperone Hsp90 has been documented as a pivotal factor participating in GR complex stabilization, and only after dislocation of Hsp90 is GR translocated to the nucleus [30]. The imbalance of Hsp90/GR $\alpha$ may be an important cause of GC resistance, an elevated Hsp90/ GR $\alpha$ ratio affects the sensitivity to ligands at a step that occurs after receptor initiation [31]. Hence, we assessed Hsp90 linked to GR $\alpha$ in MM.1R. Hsp90 expression decreased gradually with increasing EPA concentration.

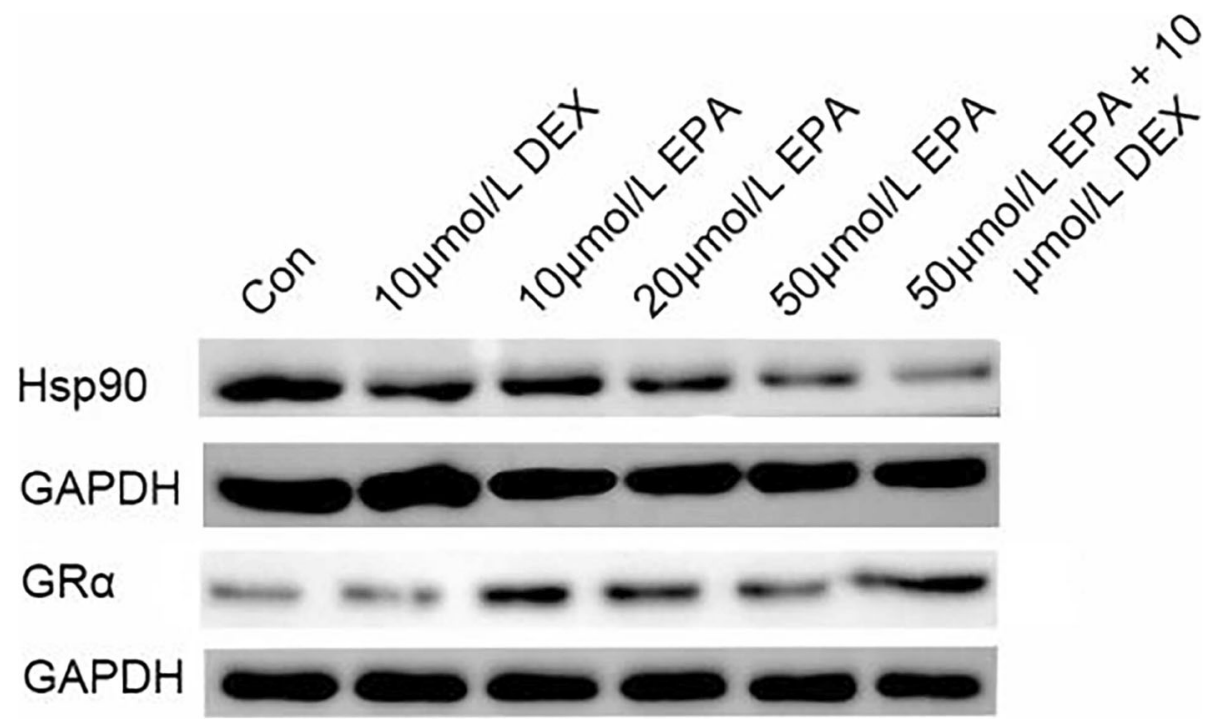

Fig. 2 Western blot analysis of Hsp90 and GRa protein expression. MM.1R cells were treated with different concentrations of EPA for $24 \mathrm{~h}$, and Western blot analyses were performed with antibodies against Hsp90 and GRa, or GAPDH. Results were representative of 3 independent experiments with similar results 
We additionally assessed the ratio of Hsp90 to GR $\alpha$ expression levels and established that the ratio decreased gradually with increasing EPA concentration. These data suggest that EPA decreases Hsp90 protein expression in the GR complex and influences GR function, leading to its enhanced responsivity to glucocorticoids.

In summary, our observations suggest that EPA has potential applications as a new effective treatment for the reversal of glucocorticoid resistance in multiple myeloma. The fact that EPA is active at physiological concentrations could necessitate further investigations of its clinical efficacy in MM patients.

\section{Acknowledgments}

We thank Nature Research Editing Service: (https://authorservices. springernature.com/language-editing/) for editing this manuscript.

\begin{abstract}
Authors' contributions
Shenghao Wu participated in the design of the study, carried out the acquisition of data, and participated in drafting the manuscript. Yuemiao Chen and Xueshuang Wang participated in the design of the study and the acquisition of data. Shanshan Weng was in charge of data gathering and computer programming for all data analyses. Wenjin Zhou participated in the design of the study. Zhen Liu conceived of the study, participated in the design and coordination, and drafted the manuscript. All authors read and approved the final manuscript. They all gave final approval of the manuscript and agree to be accountable for its integrity.
\end{abstract}

\section{Funding}

This study was supported in part by the project of Zhejiang Province Medical and Health Science and Technology Plan (No.2016RCB018).

\section{Availability of data and materials}

The datasets used and/or analysed during the current study available from the corresponding author on reasonable request.

\section{Declarations}

Ethics approval and consent to participate

Not applicable.

\section{Consent for publication}

Not applicable.

\section{Competing interests}

The authors declare that they have no competing interests.

Received: 16 February 2021 Accepted: 22 September 2021

Published online: 03 October 2021

\section{References}

1. Faict S, Muller J, De Veirman K, De Bruyne E, Maes K, Vrancken L, et al. Exosomes play a role in multiple myeloma bone disease and tumor development by targeting osteoclasts and osteoblasts. Blood Cancer J. 2018;8(11):105. https://doi.org/10.1038/s41408-018-0139-7.

2. Moloudizargari M, Abdollahi M, Asghari MH, Zimta AA, Neagoe IB, Nabavi SM. The emerging role of exosomes in multiple myeloma. Blood Rev. 2019; 38:100595. https://doi.org/10.1016/j.blre.2019.100595.

3. Chauhan D, Anderson KC. Mechanisms of cell death and survival in multiple myeloma (MM): therapeutic implications. Apoptosis. 2003;8(4):337-43. https://doi.org/10.1023/A:1024164700094.

4. Vogl DT, Dingli D, Cornell RF, Huff CA, Jagannath S, Bhutani D, et al. Selective inhibition of nuclear export with Oral Selinexor for treatment of relapsed or refractory multiple myeloma. J Clin Oncol. 2018;36(9):859-66. https://doi.org/10.1200/JCO.2017.75.5207.

5. Moalli P, Pillay S, Weiner D, Leikin $R$, Rosen S. A mechanism of resistance to glucocorticoids in multiple myeloma: transient expression of a truncated glucocorticoid receptor mRNA. Blood. 1992;79(1):213-22. https://doi.org/1 0.1182/blood.V79.1.213.213

6. Hollenberg SM, Weinberger C, Ong ES, Cerelli G, Oro A, Lebo R, et al. Primary structure and expression of a functional human glucocorticoid receptor cDNA. Nature. 1985;318(6047):635-41. https://doi.org/10.1038/31 $8635 \mathrm{a} 0$.

7. Leung DYM, Hamid Q, Vottero A, Szefler SJ, Surs W, Minshall E, et al. Association of Glucocorticoid Insensitivity with increased expression of glucocorticoid receptor ß. J Exp Med. 1997;186(9):1567-74. https://doi.org/1 0.1084/jem.186.9.1567.

8. Oakley RH, Jewell CM, Yudt MR, Bofetiado DM, Cidlowski JA. The Dominant Negative Activity of the Human Glucocorticoid Receptor $\beta$ Isoform. Specificity and mechanisms of action. J Biol Chem. 1999;274(39):27857-66. https://doi.org/10.1074/jbc.274.39.27857

9. Kirschke E, Goswami D, Southworth D, Griffin PR, Agard DA. Glucocorticoid receptor function regulated by coordinated action of the Hsp90 and Hsp70 chaperone cycles. Cell. 2014;157(7):1685-97. https://doi.org/10.1016/j.cell.2 014.04.038.

10. Kang Kl, Meng X, Devin-Leclerc J, Bouhouche I, Chadli A, Cadepond F, et al. The molecular chaperone Hsp90 can negatively regulate the activity of a glucocorticosteroid-dependent promoter. Proc Natl Acad Sci U S A. 1999; 96(4):1439-44

11. Matysiak M, Makosa B, Walczak A, Selmaj K. Patients with multiple sclerosis resisted to glucocorticoid therapy: abnormal expression of heat-shock protein 90 in glucocorticoid receptor complex. Mult Scler. 2008;14(7):91926. https://doi.org/10.1177/1352458508090666.

12. Calon F, Cole G. Neuroprotective action of omega-3 polyunsaturated fatty acids against neurodegenerative diseases: evidence from animal studies. Prostaglandins Leukot Essent Fat Acids. 2007;77(5):287-93. https://doi.org/1 0.1016/j.plefa.2007.10.019

13. Calviello G, Serini S, Piccioni E, Pessina G. Antineoplastic effects of $\mathrm{N}^{-3}$ polyunsaturated fatty acids in combination with drugs and radiotherapy: preventive and therapeutic strategies. Nutr Cancer. 2009;61(3):287-301. https://doi.org/10.1080/01635580802582777.

14. Lu J, Borthwick F, Hassanali Z, Wang Y, Mangat R, Ruth M, et al. Chronic dietary n-3 PUFA intervention improves dyslipidaemia and subsequent cardiovascular complications in the JCR:LA-cp rat model of the metabolic syndrome. Br J Nutr. 2011;105(11):1572-82. https://doi.org/10.1017/S0007114 510005453

15. Wall R, Ross RP, Fitzgerald GF, Stanton C. Fatty acids from fish: the antiinflammatory potential of long-chain omega-3 fatty acids. Nutr Rev. 2010; 68(5):280-9. https://doi.org/10.1111/j.1753-4887.2010.00287.x.

16. Asghari $\mathrm{MH}$, Ghobadi $\mathrm{E}$, Moloudizargari M, Fallah M, Abdollahi M. Does the use of melatonin overcome drug resistance in cancer chemotherapy? Life Sci. 2018;196:143-55. https://doi.org/10.1016/j.lfs.2018.01.024

17. Asghari MH, Moloudizargari M, Ghobadi E, Fallah M, Abdollahi M. Melatonin as a multifunctional anti-cancer molecule: implications in gastric cancer. Life Sci. 2017;185:38-45. https://doi.org/10.1016/j.lfs.2017.07.020

18. Moloudizargari $\mathrm{M}$, Asghari $\mathrm{MH}$, Abdollahi M. Modifying exosome release in cancer therapy: how can it help? Pharmacol Res. 2018;134:246-56. https:// doi.org/10.1016/j.phrs.2018.07.001.

19. Siddiqui RA, Harvey KA, Xu Z, Bammerlin EM, Walker C, Altenburg JD. Docosahexaenoic acid: A natural powerful adjuvant that improves efficacy for anticancer treatment with no adverse effects. Biofactors. 2011;37(6):399_ 412. https://doi.org/10.1002/biof.181.

20. Chiu LCM, Wong EYL, Ooi VEC. Docosahexaenoic acid modulates different genes in cell cycle and apoptosis to control growth of human leukemia $\mathrm{HL}$ 60 cells. Int J Oncol. 2004;25(3):737-44. https://doi.org/10.3892/ijo.25.3.737.

21. Shirota T, Haji S, Yamasaki M, Iwasaki T, Hidaka T, Takeyama Y, et al. Apoptosis in human pancreatic cancer cells induced by eicosapentaenoic acid. Nutrition. 2005;21(10):1010-7. https://doi.org/10.1016/j.nut.2004.12.013.

22. Colas S, Mahéo K, Denis F, Goupille C, Hoinard C, Champeroux P, et al. Sensitization by Dietary Docosahexaenoic Acid of Rat Mammary Carcinoma to Anthracycline: A Role for Tumor Vascularization. Clin Cancer Res. 2006; 12(19):5879-86. https://doi.org/10.1158/1078-0432.CCR-06-0386.

23. Sturlan S, Baumgartner M, Roth E, Bachleitner-Hofmann T. Docosahexaenoic acid enhances arsenic trioxide-mediated apoptosis in arsenic trioxideresistant HL-60 cells. Blood. 2003:101(12):4990-7. https://doi.org/10.1182/ blood-2002-08-2391.

24. Vibet S, Mahéo K, Goré J, Dubois P, Bougnoux P, Chourpa I. Differential Subcellular Distribution of Mitoxantrone in Relation to Chemosensitization 
in Two Human Breast Cancer Cell Lines. Drug Metab Dispos. 2007;35(5):822-8. https:/doi.org/10.1124/dmd.106.013474.

25. Daak AA, Elderdery AY, Elbashir LM, Mariniello K, Mills J, Scarlett G, et al. Omega $3(n-3)$ fatty acids down-regulate nuclear factor-kappa B (NF-KB) gene and blood cell adhesion molecule expression in patients with homozygous sickle cell disease. Blood Cell Mol Dis. 2015;55(1):48-55. https://doi.org/10.1016/j.bcmd.2015.03.014.

26. Lee JY, Zhao L, Youn HS, Weatherill AR, Tapping R, Feng L, et al. Saturated fatty acid activates but polyunsaturated fatty acid inhibits toll-like receptor 2 dimerized with toll-like receptor 6 or 1. J Biol Chem. 2004;279(17):16971-9. https://doi.org/10.1074/jbc.M312990200.

27. Schley PD, Jijon $H B$, Robinson LE, Field CJ. Mechanisms of omega-3 fatty acid-induced growth inhibition in MDA-MB-231 human breast cancer cells. Breast Cancer Res Treat. 2005;92(2):187-95. https://doi.org/10.1007/s10549005-2415-Z.

28. Wang Y, Lin QW, Zheng PP, Zhang JS, Huang FR. DHA inhibits protein degradation more efficiently than EPA by regulating the PPARY/NFKB pathway in C2C12 Myotubes. Biomed Res Int. 2013;2013:318981-9. https:// doi.org/10.1155/2013/318981.

29. Picou F, Debeissat C, Bourgeais J, Gallay N, Ferrié E, Foucault A, et al. n-3 polyunsaturated fatty acids induce acute myeloid leukemia cell death associated with mitochondrial glycolytic switch and Nrf2 pathway activation. Pharmacol Res. 2018;136:45-55. https://doi.org/10.1016/j.phrs.201 8.08.015.

30. Rajapandi T, Greene LE, Eisenberg E. The molecular chaperones Hsp90 and Hsc70 are both necessary and sufficient to activate hormone binding by glucocorticoid receptor. J Biol Chem. 2000;275(29):22597-604. https://doi. org/10.1074/jbc.M002035200.

31. Tissing WJE, Meijerink JPP, den Boer ML, Brinkhof B, Pieters R. mRNA expression levels of (co) chaperone molecules of the glucocorticoid receptor are not involved in glucocorticoid resistance in pediatric ALL. Leukemia. 2005;19(5):727-33. https://doi.org/10.1038/sj.leu.2403681.

\section{Publisher's Note}

Springer Nature remains neutral with regard to jurisdictional claims in published maps and institutional affiliations.

Ready to submit your research? Choose BMC and benefit from:

- fast, convenient online submission

- thorough peer review by experienced researchers in your field

- rapid publication on acceptance

- support for research data, including large and complex data types

- gold Open Access which fosters wider collaboration and increased citations

- maximum visibility for your research: over $100 \mathrm{M}$ website views per year

At $\mathrm{BMC}$, research is always in progress.

Learn more biomedcentral.com/submissions 